\title{
DETERMINANTS OF MULTIDIMENSIONAL POVERTY TRANSITIONS AMONG RURAL HOUSEHOLDS IN NIGERIA
}

\author{
Abimbola ADEPOJU * (D), Olaniyi OYEWOLE
}

\author{
Address: \\ University of Ibadan, Faculty of Agriculture, Department of Agricultural Economics, University of Ibadan, Oyo State, \\ Nigeria \\ * Corresponding author:abimbola.adepoju@yahoo.com
}

\begin{abstract}
Despite the progress in poverty reduction globally, millions of people are either near or living in severe multidimensional poverty in Nigeria. This study examined multidimensional poverty transitions in rural Nigeria, employing the Alkire and Foster measure of multidimensional poverty, Markov model of poverty transitions and the multinomial logistic regression model for analysis. Results showed that multidimensional poverty among rural households in Nigeria was mainly chronic (46.5\%) while education and assets dimensions contributed most to the incidence and severity of multidimensional poverty among the households respectively. Educational and marital status, household size and number of assets owned influenced transient poverty while tertiary education, household size and number of assets owned influenced chronic poverty. The enactment and implementation of relevant laws and policies against the marginalization of the poor and vulnerable with respect to ownership of assets and intensification of efforts and incentives, aimed at encouraging human capital development, is key in the fight against poverty in rural Nigeria.
\end{abstract}

Keywords: Multidimensional Poverty, Transitions, Rural households, Nigeria JEL: I32, D01

\section{INTRODUCTION}

In its multidimensional nature, poverty is the source of all human and social ills capable of constraining the creative ability of man, making him think of just mere existence (Chukwuma, 2013). The poor experience a sense of voicelessness, powerlessness, exposure to ill treatment, gross inability to influence key decisions affecting their lives as well as inadequate social networking within the institutions of state and society (World Bank, 2001). Some of these broader aspects of poverty are captured in the concept of multidimensional poverty which concentrates on deprivations in the living standard of a population in terms of functioning failures of different quality of life attributes such as per capita real GDP, life expectancy at birth and educational attainment (Chakravarty, 2006). In 104 developing countries, 1.2 billion people had an income of $\$ 1.25$ or less a day but the multidimensional poverty headcount for 91 developing countries was an estimated 1.5 billion people-as measured by the Multidimensional Poverty Index (MPI). This is owing to the fact that the MPI measures not only the proportion of people deprived but also the intensity of deprivation for each poor household. Based on these intensity thresholds, people are then classified as near multidimensionally poor, multidimensionally poor or in severe poverty, respectively (UNDP, 2014). According to the Multiple Indicator Cluster Survey (MICS) carried out in 2011, $18.2 \%$ and $31.4 \%$ of Nigerians live near multidimensional poverty and in severe poverty respectively. However, in 2014, $19.3 \%$ of Nigerians remained vulnerable to poverty while $25.3 \%$ lived in severe poverty (OPHDI, 2014). While there is an obvious decline in the number of people living in severe multidimensional poverty, there is an apparent increase in the number of people living near or vulnerable to multidimensional poverty suggesting that households do not remain in a steady state but move in and out of poverty. This introduces dynamics to multidimensional poverty assessment.

Dynamics research presents a dramatically more comprehensive understanding of poverty than static studies (Valletta, 2006; Dahl et al. 2008). While static studies do not track household poverty spells over time (Gottschalk et al. 1994), dynamics or longitudinal research traces the same individuals or households over time and so is able to record stories of change. It also helps explain the fluidity of movement in and out of poverty and the complexity of policy solutions required for an inclusive social protection mechanism. This is especially needed in rural communities where multidimensional poverty is most prominent. According to OPHDI (2014), about $85 \%$ of the worlds multidimensionally poor live in rural areas. The percentage of rural households living in multidimensional poverty is even more in Africa. For instance, in Somalia, it affects $60 \%$ of the population in urban households and over $95 \%$ of the population in rural households while in Burkina Faso, $43 \%$ and 94\%, in Niger $56 \%$ and $96 \%$ and in Ethiopia 54\% and $96 \%$ of urban and rural households respectively (NBS, 2005). In Nigeria, the severity of poverty has also been found to be more pronounced in the rural areas (IFAD, 2012). 
Successive governments have adopted various poverty alleviation strategies such as National Fadama Development Project I, II and III, Community Social Development Projects, Seven Point Agenda and Vision 20-2020. Sadly, their level of social impact leaves much to be desired as they have failed to achieve the objectives for which they were established (Ovwasa, 2000; Adesopo, 2008; Omotola, 2008). The failure of these measures has been ascribed to political and policy instability, lack of mechanisms for the sustainability of the programs and lack of effective targeting mechanisms for the poor (Obadan, 2001; Garba, 2006).

Targeting mechanisms become effective in poverty alleviation efforts if poverty is treated as being multidimensional and if they emanate from a dynamic analysis of poverty (Maggio, 2004, Thorbecke, 2005; Kay, 2006; Justino et al., 2008). This understanding among researchers interested in the well-being of households (urban and rural) over time has resulted in a number of empirical studies on multidimensional poverty both home and abroad (Sen, 1999; Gass and Adetunmbi, 2000; Oyeyomi, 2003; Alkire and Foster, 2007; Adeoti, 2014). While these studies have examined the trend, determinants, incidence and spatial dimension of multidimensional poverty, there have been very few studies on the dynamics of multidimensional poverty most especially in sub-Saharan Africa where $29 \%$ of the multidimensionally poor reside (OPHDI, 2014). In fact, to the best of our knowledge, there has been no study on multidimensional poverty transitions of rural households in Nigeria. Apart from contributing to scarce literature on multidimensional poverty transitions in Nigeria, this study will also allow for the identification of the dimensions in which multiple deprivations have been reduced the most over time. This would lead to better understanding of what policies worked and what practical applications need to be modified. Identifying those who remain multidimensionally poor and those who are likely to become multidimensionally poor will go a long way in assisting concerned stakeholders in formulating strategies not only to reduce the present menace of multidimensional poverty in Nigeria but also prevent possible increase in the number of the multidimensionally poor.

\section{DATA AND METHODS}

The scope of the study is rural Nigeria representing $49.7 \%$ of the country's population. The country has 36 states plus the Federal Capital Territory (FCT) - Abuja. The climate of the country generally falls within the humid tropics and the country is located close to the equator. High humidity is experienced from February to November in the South and from June to September in the North. Low humidity coincides with the dry season. Annual rainfall decreases Northward; rainfall ranges from about 2000 millimeters in the coastal zone to 500-700 millimeters in the North (Library of Congress, 2008). The presence of multiple vegetation zones, abundant rain, surface water and underground water resources and moderate climatic extremes, allow for production of diverse food and cash crops by over $60 \%$ of the population making the agricultural sector to be the chief employer of the country's total labour force, providing livelihood for about 90 percent of the rural population (IFAD, 2012).

The secondary data used in this study is the General Household Survey-Panel collected by the National Bureau of Statistics in conjunction with the Federal Ministry of Agriculture and Rural Development (FMA\&RD), the National Food Reserve Agency (NFRA), the Bill and Melinda Gates Foundation (BMGF) and the World Bank (WB). Both urban and rural enumeration areas (EAs) were canvassed. However, this study utilized the rural EAs only. The first wave of the GHS-Panel was carried out in two visits to the panel households (post-planting visit in August-October 2010 and post-harvest visit in FebruaryApril 2011). The second wave of the GHS-Panel was also carried out in two visits (post-planting visit in September - November 2012 and post-harvest visit in February-April 2013). Information was obtained from the same set of households in wave one to track households that moved between wave one and wave two and households that moved during wave two, that is between the post planting visit and the post-harvest visit. There was some attrition of households between the post-planting and post-harvest visits and consequently between the two waves. This was due to the inability to relocate the households who were not at home or moved away. Thus the number of people varied between the two waves.

Households were selected for the GHS panel using the two-stage probability sampling procedure. In the first stage, Primary Sampling Units (PSUs) also known as Enumeration Areas (EAs) were chosen. These were selected based on probability proportionate to size (PPS) of the total EAs in each state and Federal Capital Territory (FCT), Abuja and the total households listed in those EAs. A total of 500 EAs were selected using this method. The second stage involved the selection of households employing the systematic selection of ten (10) households per EA. In all, 500 clusters/EAs were canvassed and 5,000 households were interviewed (3,370 rural households and 1,630 urban households). However, only 2,746 rural households with complete and relevant data in wave 1 and 2 constituted the sample size for this study.

Alkire and Foster (2011) multidimensional poverty measures, Markov model of poverty transitions and multinomial logistic regression were applied to examine the multidimensional poverty status of households in rural Nigeria and the relative contributions of dimensions. Five dimensions to multidimensional poverty were chosen based on literature (Alkire and Foster, 2011, Alkire and Santos, 2010); some enduring consensus, particularly surrounding human rights, the Millennium Development Goals (MDGs), psychological accounts of basic needs, universal values and data availability. The dimensions are; Housing, Sanitation, Education, Health and Assets. For simplicity, the dimensions were equally weighted. That is, each dimension carried a weight of $1 / 5$ and as such the weights of the dimensions sum up to 1 . The equal weighting between the dimensions follows the HDI convention, upon which a critical literature has developed (e.g, Chowdhury and Squire, 2006). 
Table 1 Dimensions, indicators, deprivation cut-offs and weights of MPI

\begin{tabular}{|c|c|c|}
\hline Dimension (Weight) & Indicator (Weight) & Deprivation cut-off \\
\hline \multirow[t]{5}{*}{ Housing (1/5) } & Floor Material (1/25) & Households live in a house with mud floor \\
\hline & Wall Material $(1 / 25)$ & Households live in a house with mud wall \\
\hline & Roof Material (1/25) & Households with inadequate roofing material (grass) \\
\hline & Cooking Fuel (1/25) & $\begin{array}{l}\text { Households using firewood and coal as main source of } \\
\text { cooking fuel }\end{array}$ \\
\hline & Lighting Fuel (1/25) & $\begin{array}{l}\text { Households without electricity and other improved sources as } \\
\text { main lighting material. }\end{array}$ \\
\hline \multirow[t]{2}{*}{ Sanitation $(1 / 5)$} & Toilet type $(1 / 10)$ & $\begin{array}{l}\text { Households using unimproved toilet facilities such as } \\
\text { uncovered pit latrine, bucket toilet and hang toilet (United } \\
\text { Nations, 2003). }\end{array}$ \\
\hline & Source of Drinking Water $(1 / 10)$ & $\begin{array}{l}\text { Households using water from an unimproved source like } \\
\text { open wells, open springs and surface water (United Nations, } \\
\text { 2003). }\end{array}$ \\
\hline \multirow[t]{2}{*}{ Education $(1 / 5)$} & Ever attended school (1/10) & Household head never attended school \\
\hline & $\begin{array}{l}\text { Household head having at least primary } \\
\text { education }(1 / 10)\end{array}$ & $\begin{array}{l}\text { Household head does not have at least } 6 \text { years of formal } \\
\text { education (United Nations, 2003). }\end{array}$ \\
\hline \multirow[t]{2}{*}{ Health $(1 / 5)$} & Suffer any form of illness $(1 / 10)$ & Household head suffers from any form of illness \\
\hline & Activities stopped due to illness $(1 / 10)$ & Household head stopped activities as a result of such illness. \\
\hline \multirow[t]{2}{*}{ Assets (1/5) } & Asset Ownership (1/10) & radio, house, television, telephone \\
\hline & Land Ownership (1/10) & Household does not own agricultural land \\
\hline
\end{tabular}

Sources: Normative choice by authors with reference to the data available, UNDP (2010) and Alkire and Santos (2014).

The change in poverty over two time periods (waves) composed of four different seasons in this study can be due to the effect of changes in the incidence of poverty or intensity of poverty or the interaction between the two (Alkire et al., 2011). Following Adeoti (2014), this change was assessed by considering either the absolute change across the two time periods or the percentage change in poverty. The absolute change is the difference in the level of any focal indicator across two time periods while the percentage change in poverty expresses the change relative to the initial poverty level.

Movement of households into and out of multidimensional poverty during the two waves was examined using the spells approach of poverty decomposition and the Markov model employed by Barrientos and Mase (2012), Adepoju (2012), Finn and Leibbrandt (2013). A household that is multidimensionally poor in only one period (wave) is said to be experiencing transient multidimensional poverty while a household that is poor in both periods is considered to be chronically poor.

The multinomial logit (MNL) model following Cunguara (2008) was used to analyse the factors influencing the shifts in multidimensional poverty status between the two waves (wave 1 and 2).

The MNL model is explicitly expressed as Eq. 1-4.

$$
\begin{aligned}
& Y_{1}=\propto_{1}+\beta_{11} X_{1}+\beta_{21} X_{2} \ldots \ldots \ldots \ldots \ldots \ldots \beta_{n} X_{n}+\epsilon_{i}(1) \\
& Y_{2}=\propto_{2}+\beta_{12} X_{1}+\beta_{22} X_{2} \quad \ldots \ldots \ldots \ldots \ldots \ldots \beta_{n} X_{n}+\epsilon_{i}(2) \\
& Y_{3}=\propto_{3}+\beta_{13} X_{1}+\beta_{23} X_{2} \quad \ldots \ldots \ldots \ldots \ldots . \beta_{n} X_{n}+\epsilon_{i}(3) \\
& Y_{0}=\propto_{0}+\beta_{10} X_{1}+\beta_{20} X_{2} \quad \ldots \ldots \ldots \ldots \ldots \beta_{n} X_{n}+\epsilon_{i}(4)
\end{aligned}
$$

Where:

$Y_{1}$ those who were multidimensionally poor in both periods (i.e. chronically poor).

$Y_{2}$ those who were multidimensionally poor in the first period, but not in the second period (i.e. transitory poor). $Y_{3}$ those who were non-poor in the first period, but multidimensionally poor in the second period (i.e. transitory poor).

$Y_{0}$ those who were non-poor in both periods (i.e. always non-poor).

$X_{1} \ldots X_{n}$ represents vector of the explanatory variables.

$\beta_{1} \ldots \beta_{n}$ represents the parameter coefficients.

$\epsilon_{i}$ represents the independently distributed error terms. $\propto_{0} \ldots \propto_{3}$ shows the intercept or constant terms.

Specifically, the independent variables used in the model are as follows;

$X_{1}$ Sex (male $=1,0$ if otherwise) $; X_{2}$ Age (in years) $; X_{3}$ Marital Status (Never Married $=1,0$ if otherwise); $X_{4}$ Marital Status (Separated/Divorced $=1,0$ if otherwise); $X_{5}$ Marital Status (Widowed $=1,0$ if otherwise); $X_{6}$ Household Size (number); $X_{7}$ Access to Credit (yes $=1,0$ if otherwise); $X_{8}$ Household Head has secondary education (yes $=1,0$ if otherwise); $X_{9}$ Household Head has tertiary education (yes $=1,0$ if otherwise); $X_{10}$ Monthly Expenditure (Naira); $X_{11}$ House Ownership (Owned $=1,0$ if otherwise); $X_{12}$ Distance to Health Centre (Minutes); $X_{13}$ Membership in Cooperative (yes $=1,0$ if otherwise); $X_{14}$ Access to Remittances (yes $=1,0$ if otherwise);

$\mu$ Error term.

\section{RESULTS AND DISCUSSION}

The mean age of respondents was 49.7 years while almost all the respondents have one form of formal education or the other but with majority having primary education (Table 2). This could be attributed to the fact that most rural dwellers seem not to consider secondary and postsecondary education as being vital for rural-life sustenance. Also, more than four-fifths of the sampled household heads were married having a mean household size of approximately 6 members per household with the 
majority residing in the North Western zone of Nigeria. The average monthly expenditure of the respondents stood at $29,451.00$.

Table 2 Selected socio-economic characteristics of respondents

\begin{tabular}{|c|c|c|}
\hline Variables & Frequency & Percentage \\
\hline \multicolumn{3}{|l|}{ Age (in years) } \\
\hline$\leq 30$ & 288 & 10.5 \\
\hline $31-60$ & 1841 & 67.0 \\
\hline $61-90$ & 606 & 22.1 \\
\hline$>90$ & 11 & 0.4 \\
\hline Mean & 49.7 & \\
\hline SD & 15.1 & \\
\hline \multicolumn{3}{|l|}{ Marital Status } \\
\hline Never Married & 66 & 2.40 \\
\hline Married & 2244 & 81.8 \\
\hline Separated/Divorced & 76 & 2.70 \\
\hline Widowed & 360 & 13.1 \\
\hline \multicolumn{3}{|l|}{ Household Size } \\
\hline $1-5$ & 1260 & 45.9 \\
\hline $6-10$ & 1221 & 44.5 \\
\hline $11-15$ & 247 & 9.0 \\
\hline$>15$ & 18 & 0.6 \\
\hline Mean & 6.1 & \\
\hline SD & 3.1 & \\
\hline \multicolumn{3}{|l|}{ Educational Status } \\
\hline No Formal Education & 208 & 7.6 \\
\hline Primary & 2280 & 83.0 \\
\hline Secondary & 19 & 0.7 \\
\hline Tertiary & 239 & 8.7 \\
\hline \multicolumn{3}{|l|}{ Geopolitical Zone } \\
\hline North Central & 521 & 19.0 \\
\hline North East & 434 & 15.8 \\
\hline North West & 621 & 22.6 \\
\hline South East & 512 & 18.7 \\
\hline South South & 468 & 17.0 \\
\hline South West & 190 & 6.9 \\
\hline \multicolumn{3}{|l|}{ Monthly Expenditure } \\
\hline$\leq 40000$ & 2219 & 80.8 \\
\hline $40001-80000$ & 468 & 17.0 \\
\hline $80001-120000$ & 48 & 1.7 \\
\hline$>120000$ & 11 & 0.5 \\
\hline Mean & $¥ 29,451$ & \\
\hline SD & N18,655 & \\
\hline
\end{tabular}

Source: Own computation based on GHS (2011 \& 2013) panel data

Table 3 presents the estimated multidimensional poverty indices (headcount of poverty, adjusted head count of poverty, adjusted poverty gap and the adjusted poverty severity measure) based on different cut-offs $(k)$.
As shown in Table 1, the multidimensional poverty estimates were derived using five dimensions; sanitation, housing, health, education and assets with equal weights assigned to all. For each dimension, thresholds were set which is the first cut-off to identify if the household is deprived in that dimension. A second cut-off, $k$ was set which states the number of dimensions in which a household can be deprived to be considered multidimensionally poor. It can be observed from Table 3 that in both waves, the headcount $(\mathrm{H})$ and the adjusted headcount ratio $\left(\mathrm{M}_{0}\right)$ decreased with increase in $k$. This is in accordance with a priori expectation that the number of multidimensionally poor households reduces as the number of dimensions used increases and is consistent with the findings of Batana (2008) and Adeoti (2014).

With the number of deprivations experienced by the households at $k$ equals 1 , the poverty head count ratio stood at $92 \%$ in wave 1 and about $95 \%$ in wave 2 indicating that only a few of the panel households were not deprived in at least one dimension. At $k=3$, the midpoint of the considered dimensions, all indices of poverty increased from wave 1 to wave 2 . While the poverty head count increased from $34.6 \%$ to $43.1 \%$, the intensity of poverty increased from $73.4 \%$ to $74.2 \%$. These changes in the percentage the poor $(\mathrm{H})$ and the share of deprivations in which the poor are deprived (A) accounted for the increase in the multidimensional poverty index $\left(\mathrm{M}_{0}\right)$ from 0.254 to 0.320 . However, an increase in $k$ decreased $\mathrm{M}_{0}$. This implies that as the percentage of households estimated poor is reducing, the intensity of poverty among the poor is increasing.

The adjusted poverty gap $\left(\mathrm{M}_{1}\right)$ values at different cutoffs $(k)$ indicates how far the poor are from the poverty line and what it will take to move the poor out of poverty. However, for a multidimensional poverty measure, the poverty line is not clearly defined. Hence, this measure is subjective. However, a high adjusted poverty gap implies the farther away the poor are from the poverty line. The adjusted poverty severity $\left(\mathrm{M}_{2}\right)$ for households in rural Nigeria is also subjective but points out that the larger the value of $\mathrm{M}_{2}$, the harder it is to eliminate poverty.

The changes in MPI, head count ratio and intensity of poverty at $k=3$ as presented in Table 4 for poverty headcount $(\mathrm{H})$ than intensity (A). This implies that efforts at alleviating poverty in rural Nigeria should focus more on reducing the number of the multidimensionally poor than in reducing the deprivation share of each of the multidimensionally poor. This agrees with the findings of Alkire et al. (2011) that changes in MPI in Nigeria, Lesotho and Kenya are achieved by reduction in $\mathrm{H}$ and hardly by a reduction in A.

Table 3 Household multidimensional poverty indices

\begin{tabular}{|c|c|c|c|c|c|c|c|c|c|c|c|}
\hline \multirow[t]{2}{*}{$\bar{K}$} & \multicolumn{6}{|l|}{ Wave 1} & \multicolumn{5}{|l|}{ Wave 2} \\
\hline & $\mathrm{M}_{0}$ & $\mathrm{H}_{\mathrm{o}}$ & & A & $\mathrm{M}_{1}$ & $\mathrm{M}_{2}$ & $\mathrm{M}_{0}$ & $\mathrm{H}_{\mathrm{o}}$ & A & $\mathrm{M}_{1}$ & $\mathrm{M}_{2}$ \\
\hline 1 & 0.419 & & 0.920 & 0.455 & 0.39 & 0.383 & 0.482 & 0.946 & 0.510 & 0.45 & 0.442 \\
\hline 2 & 0.354 & & 0.596 & 0.594 & 0.33 & 0.321 & 0.438 & 0.727 & 0.602 & 0.41 & 0.400 \\
\hline 3 & 0.254 & & 0.346 & 0.734 & 0.23 & 0.230 & 0.320 & 0.431 & 0.742 & 0.29 & 0.286 \\
\hline 4 & 0.147 & & 0.168 & 0.875 & 0.13 & 0.131 & 0.193 & 0.221 & 0.873 & 0.17 & 0.170 \\
\hline 5 & 0.065 & & 0.065 & 1.000 & 0.06 & 0.058 & 0.084 & 0.084 & 1.000 & 0.07 & 0.075 \\
\hline
\end{tabular}

Source: Authors' computation based on GHS (2011 \& 2013) panel data 
Table 4 Changes in MPI, Headcount Ratio (H) and Intensity of Poverty (A) at $k=3$

\begin{tabular}{lrrrrrr}
\hline & \multicolumn{1}{c}{$\mathrm{M}_{0}$} & \multicolumn{2}{c}{$\mathrm{H}$} & \multicolumn{3}{c}{$\mathrm{A}$} \\
Waves & Wave 1 & Wave 2 & Wave 1 & Wave 2 & Wave 1 & Wave 2 \\
\hline & 0.254 & 0.32 & 0.346 & 0.431 & 0.734 & 0.742 \\
Annual Absolute Change & & 0.011 & & 0.014 & & 0.001 \\
Annual Percent Change & & 4.33 & 4.1 & 0.18 \\
\hline
\end{tabular}

Source: Authors' Computation based on GHS (2011 \& 2013) panel data

Table 5 Relative Contributions of Dimensions to MPI

\begin{tabular}{|c|c|c|c|c|c|}
\hline$K$ & $\begin{array}{r}\text { Housing } \\
\text { contribution }(\%)\end{array}$ & $\begin{array}{r}\text { Sanitation } \\
\text { contribution }(\%)\end{array}$ & $\begin{array}{r}\text { Education } \\
\text { contribution }(\%)\end{array}$ & $\begin{array}{r}\text { Health } \\
\text { contribution }(\%)\end{array}$ & $\begin{array}{r}\text { Assets } \\
\text { contribution (\%) }\end{array}$ \\
\hline \multicolumn{6}{|c|}{ Wave 1} \\
\hline 1 & 13.68 & 12.06 & 20.77 & 35.58 & 17.91 \\
\hline 2 & 15.18 & 13.42 & 23.55 & 27.13 & 20.72 \\
\hline 3 & 15.91 & 13.72 & 24.48 & 23.13 & 22.76 \\
\hline 4 & 19.39 & 16.70 & 22.50 & 19.97 & 21.44 \\
\hline 5 & 20.00 & 20.00 & 20.00 & 20.00 & 20.00 \\
\hline \multicolumn{6}{|c|}{ Wave 2} \\
\hline 1 & 13.26 & 11.85 & 18.42 & 30.62 & 25.85 \\
\hline 2 & 14.11 & 12.53 & 19.40 & 27.66 & 26.29 \\
\hline 3 & 17.02 & 14.22 & 21.27 & 23.18 & 24.32 \\
\hline 4 & 20.62 & 16.05 & 21.06 & 20.32 & 21.96 \\
\hline 5 & 20.00 & 20.00 & 20.00 & 20.00 & 20.00 \\
\hline
\end{tabular}

Source: Own computation based on GHS (2011 \& 2013) panel data

The relative contributions of dimensions to multidimensional poverty during wave 1 and 2 at different cut-offs, $k$ is shown in Table 5. The result reveals that the highest contribution is from health dimension with $35.58 \%$ and $30.62 \%$ at $k=1$ in waves 1 and 2 respectively. Thus, investments in improved health of rural dwellers in Nigeria is key in ensuring significant reduction in multidimensional poverty. While education contributed most to poverty in wave 1 , followed by health and assets at $\mathrm{k}=3$, assets contributed most to poverty in wave 2 followed by health and education. This indicates that multidimensional poverty of rural households in Nigeria can be mainly attributed to lack of access to basic education, low level of assets and poor health condition of household heads.

According to Table 6, multidimensional poverty indices increased for all zones between waves 1 and 2 except for the intensity of poverty that decreased from 0.696 to 0.662 for the South South zone. In all, the North East zone recorded the highest poverty rate followed by the North Central zone. Like all the other zones, North East and North Central zones recorded an increase in multidimensional poverty index from wave 1 to wave 2 . Notably, the intensity of poverty in those two zones was equal and the highest of all the geopolitical zones. This could be linked to large family sizes, insurgents' activities and the relatively high illiteracy level prevalent in the Northern region of Nigeria. In fact, results from the 2017 Nigeria MPI show a high incidence of poverty across the North with the intensity of deprivation in the region of above $40 \%$ for most states (MPPN, 2017). With respect to annual percentage change, rural households in South East experienced the highest percentage increase in poverty followed by the North-Central zone while the South-South had the lowest percentage increase in poverty.
The multidimensional poverty transition matrix in Table 7 indicates that $46.5 \%$ of poor households in wave 1 remained poor in wave 2 while $14.8 \%$ of poor households who were poor in wave 1 exited poverty in wave 2 . On the other hand, the percentage of households that moved into poverty in the second wave was $8.2 \%$. However, $30.5 \%$ of households were non-poor in both waves.

Arising from the findings in Table 7, figures in Table 8 indicate that chronic and transient multidimensional poverty rates were $46.5 \%$ and $23.0 \%$ respectively. This indicates that rather than most households moving into and out of poverty between periods, a majority of rural households remained multidimensionally poor between periods. Implying that poverty is predominantly chronic than transient in Nigeria.

Table 9 shows the multidimensional poverty profile of households in rural Nigeria by selected socio-economic characteristics. With respect to sex of household head, female headed households had a higher multidimensional poverty index $\left(\mathrm{M}_{0}\right)$ of 0.267 . This might not be unconnected with the traditional marginalisation of women in rural communities leading to their owning fewer assets than their male counterpart or at best, relatively low value assets. Also, women's ability to accumulate assets is often governed by norms that historically have favoured men limiting the extent of women's control over assets (Kumar and Agnes, 2014). The result also revealed that household heads between 61 and 90 years of age had the highest $\mathrm{M}_{0}$ of 0.285 while household heads between 31 and 60 years of age had the lowest $\mathrm{M}_{0}$ of 0.116 . This is expected as household heads between 31 and 60 years of age were still economically active and could multi-task to generate more income to cater for family needs. 
Table 6 Changes in MPI, headcount ratio and intensity of poverty at $k=3$ by geopolitical zones

\begin{tabular}{|c|c|c|c|c|}
\hline Geopolitical zones & Waves & $\mathrm{M}_{0}$ & $\mathrm{H}$ & A \\
\hline \multirow[t]{2}{*}{ North Central } & 1 & 0.392 & 0.499 & 0.785 \\
\hline & 2 & 0.502 & 0.631 & 0.796 \\
\hline Annual Absolute Change & & 0.018 & 0.022 & 0.002 \\
\hline Annual Percentage Change & & 4.7 & 4.4 & 0.23 \\
\hline \multirow[t]{2}{*}{ North West } & 1 & 0.202 & 0.284 & 0.711 \\
\hline & 2 & 0.253 & 0.347 & 0.729 \\
\hline Annual Absolute Change & & 0.009 & 0.011 & 0.003 \\
\hline Annual Percentage Change & & 4.1 & 3.7 & 0.42 \\
\hline \multirow[t]{2}{*}{ North East } & 1 & 0.466 & 0.594 & 0.785 \\
\hline & 2 & 0.527 & 0.658 & 0.8 \\
\hline Annual Absolute Change & & 0.01 & 0.011 & 0.003 \\
\hline Annual Percentage Change & & 2.2 & 1.8 & 0.3 \\
\hline \multirow[t]{2}{*}{ South East } & 1 & 0.169 & 0.25 & 0.676 \\
\hline & 2 & 0.262 & 0.367 & 0.714 \\
\hline Annual Absolute Change & & 0.016 & 0.02 & 0.006 \\
\hline Annual Percentage Change & & 9.2 & 7.8 & 0.9 \\
\hline \multirow[t]{2}{*}{ South South } & 1 & 0.222 & 0.319 & 0.696 \\
\hline & 2 & 0.239 & 0.361 & 0.662 \\
\hline Annual Absolute Change & & 0.003 & 0.007 & 0.006 \\
\hline Annual Percentage Change & & 1.3 & 2.2 & -0.8 \\
\hline \multirow[t]{2}{*}{ South West } & 1 & 0.161 & 0.237 & 0.679 \\
\hline & 2 & 0.193 & 0.281 & 0.687 \\
\hline Annual Absolute Change & & 0.005 & 0.007 & 0.001 \\
\hline Annual Percentage Change & & 3.3 & 3.1 & 0.02 \\
\hline
\end{tabular}

Source: Own computation based on GHS (2011 \& 2013) panel data

Table 7 Poor/Non-Poor Transition Matrix

\begin{tabular}{llrrr}
\hline \multicolumn{2}{c}{ Wave 2} & \multicolumn{1}{l}{ Poor } & Non-Poor & \multicolumn{1}{l}{ Total } \\
\hline Wave 1 & Poor & $1278(46.5)^{*}$ & $406(14.8)$ & $1684(61.3)$ \\
& Non-Poor & $224(8.2)$ & $838(30.5)$ & $1062(38.7)$ \\
& Total & $1502(54.7)$ & $1244(45.3)$ & $2746(100.0)$ \\
\hline
\end{tabular}

Note: Top number is cell frequency and number in parenthesis is cell percentage Source: Own computation based on GHS (2011 \& 2013) panel data

Similarly, households having between 11 and 15 members had the lowest multidimensional poverty index. Since family labour is usually employed in most rural communities for agricultural production, rural households with large number of members who are of working age would have more opportunity to improve their livelihood through increased production and consequently higher income (Bruck and Workneh Kebede, 2013). Households could also generate income by supplying labour to other non-farming activities to augment household resources. The educational status profile of the households revealed that household heads with primary education had the highest $\mathrm{M}_{0}$ of 0.725 followed by those with no formal education (0.492). This can be ascribed to the relatively high percentage of representative households $(83.0 \%)$ having primary education in this study and the limited opportunities available for household heads having no post primary education to be gainfully employed by any firm or establishment in this technological driven 21 st century. Also, with respect to marital status, household heads that were married had the highest $\mathrm{M}_{0}$ of 0.387 while those who were never married had the least MPI of 0.170 . This could be as a result of the added responsibilities associated with being married which could greatly reduce resources available to increase assets, acquire more education and access better health care relative to those who are still single.

Confirming the findings above, the adjusted poverty gap $\left(\mathrm{M}_{1}\right)$ values and those of adjusted poverty severity $\left(\mathrm{M}_{2}\right)$, also shown in Table 9 revealed that the households with the highest multidimensional poverty indices $\left(\mathrm{M}_{0}\right)$, which include- female-headed households, married household heads, household heads aged 61-90 years with 6 to 10 members, households having primary education and households residing in the North East zone, were also the farthest from the poverty line and as such, hardest to lift out of poverty.

Table 10 presents the results of the multinomial logit analysis of factors influencing chronic and transient multidimensional poverty in the study area. Similar sets of explanatory variables were used in each case and the relative risk ratios (RRR) associated with the different explanatory variables are presented. With a log likelihood 
of -1938.7218 and a Chi-square statistics of 2741.70 significant at $1 \%(0.000)$, the model is well fitted.

Results showed that household size, tertiary education, number of household assets acquired, house ownership and distance to health care were the significant factors affecting the likelihood of households being chronically poor. The positive coefficient of distance to health care indicates that distance to health care centre is strongly associated with chronic poverty in rural Nigeria. In other words, health care centers situated far from the residence of rural households contribute to their being chronically poor. This might be owing to the fact that additional resources which otherwise could have been used for some productive purposes by rural dwellers are expended on transportation to receive medical care. Also, when health care centers are not easily accessible, rural households might become discouraged altogether from taking the needed step or resort to unorthodox options which might worsen their situation, leaving them in an impoverished state that limits their productivity and capacity to create wealth.

The negative but significant coefficient of household size implies that as household members increase, the probability that households will experience chronic poverty decreases. Precisely, an additional member to the household reduces the likelihood of chronic poverty by 0.951 . This could be attributed to additional labour that would be supplied by the new member(s) of the household, leading to increased returns that could be used to meet other pressing deprivations. Similarly, tertiary education of household head variable had a negative coefficient, supporting the view that increased years of education decrease the probability that a household will be chronically poor. The corresponding relative risk ratio shows that having secondary education decreased the odds of being chronically poor by 0.026 . This implies that a household head with tertiary education has a higher likelihood of exiting poverty relative to the head with no formal education. This is because educated household heads are better poised to cope with risk and uncertainty.

With respect to the number of assets acquired which was negatively significant, an increase in the number of assets acquired by households reduced their duration of poverty. Put differently, a unit increase in the number of assets owned by households decreased the likelihood of households remaining multidimensionally poor by 0.953 . When assets are put into productive use, households become better off through increased income. That an increase in the number of assets reduces the chances of households remaining multidimensionally poor explains why house ownership also had a negative effect. That is, owning a house reduced the odds that households will remain chronically poor by 0.582 .
Results shown in Table 10 also indicate that household heads having tertiary education and number of household assets owned were the statistically significant factors explaining households' exit from poverty. The positive coefficient associated with tertiary education of household head suggests that development of human capital is a key determinant of rural households' exiting poverty. Formal education affords people with opportunities, through gainful employment or skills and knowledge acquisition that could ultimately lift households out of poverty. With respect to assets, the negative and significant coefficient of 0.028 indicated that additional asset acquisition reduced the odds that households will exit poverty. Purchase of additional household assets is a drain on meagre households' resources available to meet basic needs that might contribute appreciably to their exit from poverty. An exception to this is if additional household assets purchased are put to productive use.

Movement into multidimensional poverty is a function of household size, tertiary education of household head, number of household assets, distance to health centre and marital status (never married and divorced). While marital status (never married and divorced), household size and distance to health centre positively influenced the odds of entering poverty, tertiary education of household head and number of household assets had negative effects on the probability that households will become poor. The positive coefficient of household heads who were never married, that is, single household heads implies that being single increased the likelihood that a non-poor household will be poor. This might not be unconnected with the fact that single household heads, unlike married household heads, will not be able to enjoy the benefits of pulling of resources together, which to a large extent serve as a bulwark from slipping to poverty (Hokayem and Heggeness, 2013). The positive coefficient of being separated or divorced followed the same pattern as that of never married household heads. Also, positively significant in explaining movement of households into poverty was household size. That is, as the number of household members increased, the probability that households will fall into poverty increased. Specifically, an additional member to the household increased the likelihood of slipping into poverty by 1.071 . Increase in household size could be a negative force with respect to household welfare since it could exert additional pressure on limited household resources. This is especially so if there are more dependants in the household relative to adults.

Distance to health care also increased the probability that households will fall into poverty by 1.056 as shown by the positive sign which is significant at $1 \%$.

Table 8 Multidimensional Poverty Decomposition (Spells Approach)

\begin{tabular}{lrr}
\hline Multidimensional poverty status & Number of households & Percentage \\
\hline Always Multidimensionally Poor (Chronic) & 1278 & 46.5 \\
Sometimes Multidimensionally Poor (Transient) & 630 & 23.0 \\
Never Multidimensionally Poor & 838 & 30.5 \\
Total & 2746 & 100.0 \\
\hline
\end{tabular}

Source: Own computation based on GHS (2011 \& 2013) panel data 
Table 9 Multidimensional poverty profile of households by selected characteristics

\begin{tabular}{|c|c|c|c|}
\hline $\begin{array}{l}\text { Socioeconomic } \\
\text { characteristics }\end{array}$ & $\begin{array}{l}\text { Multidimensional } \\
\text { poverty index }\left(\mathrm{M}_{0}\right)\end{array}$ & $\begin{array}{l}\text { Adjusted poverty } \\
\text { gap }\left(M_{1}\right)\end{array}$ & $\begin{array}{l}\text { Adjusted poverty } \\
\text { severity }\left(\mathrm{M}_{2}\right)\end{array}$ \\
\hline \multicolumn{4}{|c|}{ Sex of Household Head } \\
\hline Male & 0.181 & 0.160 & 0.155 \\
\hline Female & 0.267 & 0.250 & 0.243 \\
\hline \multicolumn{4}{|l|}{ Age } \\
\hline$<30$ & 0.235 & 0.220 & 0.217 \\
\hline $31-60$ & 0.116 & 0.100 & 0.095 \\
\hline $61-90$ & 0.285 & 0.260 & 0.261 \\
\hline $91-120$ & 0.181 & 0.160 & 0.154 \\
\hline \multicolumn{4}{|l|}{ Household Size } \\
\hline $1-5$ & 0.224 & 0.200 & 0.218 \\
\hline $6-10$ & 0.291 & 0.270 & 0.265 \\
\hline $11-15$ & 0.240 & 0.220 & 0.218 \\
\hline$>15$ & 0.234 & 0.070 & 0.220 \\
\hline \multicolumn{4}{|l|}{ Educational Status } \\
\hline No Formal Education & 0.492 & 0.477 & 0.469 \\
\hline Primary Education & 0.725 & 0.687 & 0.668 \\
\hline Secondary Education & 0.235 & 0.219 & 0.212 \\
\hline Tertiary Education & 0.116 & 0.108 & 0.104 \\
\hline \multicolumn{4}{|l|}{ Marital Status } \\
\hline Never Married & 0.170 & 0.154 & 0.146 \\
\hline Married & 0.387 & 0.363 & 0.351 \\
\hline Separated/Divorced & 0.276 & 0.258 & 0.249 \\
\hline Widowed & 0.264 & 0.248 & 0.240 \\
\hline \multicolumn{4}{|l|}{ Geopolitical Zones } \\
\hline North Central & 0.392 & 0.356 & 0.338 \\
\hline North West & 0.202 & 0.190 & 0.183 \\
\hline North East & 0.466 & 0.436 & 0.422 \\
\hline South East & 0.169 & 0.164 & 0.162 \\
\hline South South & 0.222 & 0.209 & 0.202 \\
\hline South West & 0.161 & 0.152 & 0.147 \\
\hline
\end{tabular}

Source: Own computation based on GHS (2011 \& 2013) panel data

Table 10 Determinants of chronic and transient multidimensional poverty

\begin{tabular}{|c|c|c|c|c|c|c|c|c|c|}
\hline \multirow[b]{2}{*}{ Variable } & \multicolumn{3}{|c|}{ Chronic Poverty } & \multicolumn{3}{|c|}{ Exiting Poverty } & \multicolumn{3}{|c|}{ Moving into Poverty } \\
\hline & RRR & Coeff & Z-value & RRR & Coeff & Z-value & RRR & Coeff & Z-value \\
\hline Sex & 1.063 & 0.061 & 0.13 & 1.741 & 0.554 & 1.11 & 0.502 & -0.632 & -1.46 \\
\hline Age & 0.999 & -0.001 & -0.09 & 1.000 & 0.000 & 0.00 & 0.989 & -0.011 & -1.60 \\
\hline Never Married & 0.830 & -0.186 & -0.31 & 0.907 & -0.097 & -0.16 & 2.225 & 0.800 & $1.74 *$ \\
\hline Sep./Divorced & 1.149 & 0.139 & 0.25 & 0.706 & -0.348 & -0.58 & 2.705 & 0.995 & $1.99 * *$ \\
\hline Widowed & 1.371 & 0.135 & 0.64 & 0.736 & -0.307 & -0.59 & 1.954 & 0.670 & 1.38 \\
\hline Hh Size & 0.951 & -0.050 & $-1.69 *$ & 0.962 & -0.039 & -1.27 & 1.071 & 0.076 & $2.47 * *$ \\
\hline Credit Access & 1.264 & 0.234 & 1.10 & 1.150 & -0.140 & 0.63 & 1.309 & 0.269 & 1.30 \\
\hline Secondary & -0.006 & -14.637 & -0.03 & 0.416 & 0.878 & 0.32 & 1.088 & 0.084 & 0.07 \\
\hline Tertiary & 0.026 & -3.660 & $-7.70 * * *$ & 0.117 & 2.143 & $5.03 * * *$ & 0.340 & -1.624 & $-4.07 * * *$ \\
\hline Asset count & 0.953 & -0.048 & $-4.64 * * *$ & 0.972 & -0.02 & $-3.22 * * *$ & 0.955 & -0.046 & $-3.71 * * *$ \\
\hline Mthly Expend. & 1.000 & -0.374 & -0.09 & 1.000 & -0.06 & 1.36 & 1.000 & -0.004 & -0.94 \\
\hline House Own. & 0.582 & -0.541 & $-2.36 * *$ & 0.860 & -0.15 & -0.65 & 0.697 & -0.362 & -1.60 \\
\hline Dist. Health & 1.071 & 0.069 & $6.95 * * *$ & 1.015 & 0.01 & 1.13 & 1.056 & 0.055 & $6.33 * * *$ \\
\hline Coop. Memb. & 0.751 & -0.286 & -0.84 & 0.895 & -0.111 & -0.31 & 0.868 & -0.142 & -0.41 \\
\hline Remittances & 1.106 & 0.101 & 0.20 & 2.102 & 0.743 & 1.53 & 1.031 & 0.030 & 0.06 \\
\hline Constant & 0.003 & 31.246 & 16.37 & 0.538 & 22.406 & 11.78 & 34.5 & 9.895 & 5.30 \\
\hline
\end{tabular}

Note: $* * *, * * *$ Significant at $1 \%, 5 \%$ and $10 \%$ respectively

Source: Authors Computation from GHS panel data, 2011

Observations = 2746; $\operatorname{LR~chi}^{2}(22)=2741.70 ;$ Prob $>\mathrm{chi}^{2}=0.000$

Log likelihood $=-1938.7218 ;$ Pseudo $\mathrm{R}^{2}=0.4142$

Dependent variable: Multidimensional poverty status $(0=$ non-poor, $1=$ chronic poor, $2=$ poor-non-poor, $3=$ non poor-poor $)$, with base category poverty status $=0$. 
The implication of this is that the farther the health care centres from the residence of households, the higher the likelihood of slipping into poverty. The negative coefficient of tertiary education of household heads and the RRR value of 0.340 suggests that having tertiary education decreased the odds that a non-poor household will become poor. In other words, for those with tertiary education, there is a high likelihood that they were meeting their present needs and planning for possible future needs. In addition, for those who were yet to be gainfully employed, there is a high probability of being engaged in a profitable venture owing to the knowledge and skills already acquired which can be provided at a cost. Further, ownership of assets had a negative impact on the odds of moving into poverty. That is, an increase in assets decreased the probability of a non-poor household becoming poor. Specifically, an additional asset acquired reduced the chances of movement into poverty by 0.955 . This can be attributed to the fact that assets assist households in responding effectively by providing options for smoothing consumption in the event of economic shocks.

\section{CONCLUSIONS}

The study revealed a high incidence of multidimensional poverty in rural Nigeria and suggested that efforts at alleviating poverty in rural Nigeria should focus more on reducing the number of the multidimensionally poor than in reducing the deprivation share. Lack of access to basic education, low level of assets and poor health condition of household heads mainly contributed to multidimensional poverty in rural Nigeria. Generally, multidimensionally poor households were mainly resident in the North East zone of Nigeria, large sized, female-headed, with married and aged household heads. Multidimensional poverty in rural Nigeria is largely chronic with movement of households into and out of multidimensional poverty basically influenced by human capital (tertiary education) and number of assets owned. However, while efforts should be geared towards addressing the key factors influencing chronic multidimensional poverty, factors influencing transitions into and out of poverty among rural households should not be ignored for effective social protection. Also, efforts towards promotion of basic education for all, creation of scholarship schemes specifically targeted at encouraging rural households to pursue higher education and the enactment and implementation of relevant laws against gender discrimination and marginalization of rural women in ownership of assets are imperative policy requirements in the alleviation of multidimensional poverty in rural Nigeria.

\section{REFERENCES}

ADEOTI, A.I. (2014). Trend and determinants of multidimensional poverty in rural Nigeria. Journal of Development and Agricultural Economics, 6(5), 220-231. doi:10.5897/JDAE2013.0535

ADEPOJU, A. O. (2012). Poverty transitions in rural south west Nigeria. Global Journal of Science Frontier
Research Agriculture \& Biology, 12(2), 19-30. Retrieved from: https://globaljournals.org/item/192-povertytransitions-in-rural-south-west-nigeria

ADESOPO, A. (2008). The poverty question and the national anti-poverty programmes in Nigeria. In K. Ajayi (Ed.), public administration and public policy analysis in Nigeria (pp. 213 -227). Abuja, Nigeria: Panaf Publishing Inc.

ALKIRE, S., \& FOSTER, J. (2007). Counting and multidimensional poverty measurement (Oxford Poverty and Human Development Initiative, Working Paper No. 7). Retrieved from: https://ophi.org.uk/working-papernumber-07/

ALKIRE, S., \& FOSTER, J. (2011). Counting and multidimensional poverty measurement. Journal of Public Economics, 95(7-8), 476-487. doi: https://doi.org/10.1016/j.jpubeco.2010.11.006

ALKIRE, S., \& SANTOS, M. E. (2010). Acute multidimensional poverty: A new index for developing countries (Oxford poverty and human development initiative working Paper No. 38). Retrieved from: http://dx.doi.org/10.2139/ssrn.1815243

ALKIRE, S., \& SANTOS, M. E. (2014). Measuring acute poverty in the developing world: robustness and scope of the multidimensional poverty index. World Development Journal, 59(c), 251-274. doi: https://doi.org/10.1016/j.worlddev.2014.01.026

BARRIENTOS, A., \& MASE, J. (2012). Poverty transitions among older households in Brazil and South Africa. European Journal of Development Research, 24(4), 570-588. doi: https://doi.org/10.1057/ejdr.2012.13 BATANA, Y. (2008). Multidimensional measurement of poverty in sub-Saharan Africa. (Oxford Poverty and Human Development Initiative, Working Paper 13). Retrieved from: https://ophi.org.uk/working-papernumber-13/

BRÜCK, T., \& WORKNEH KEBEDE, S. (2013). Dynamics and divers of consumption and multidimensional poverty Evidence from rural Ethiopia. (The Institute for the Study of Labor (IZA) Discussion Paper No. 7364). Retrieved from http://ftp.iza.org/dp7364.pdf.

CHAKRAVARTY, S. R. (2006). An axiomatic approach to multidimensional poverty measurement via fuzzy sets. In A. Lemmi and G. Betti (Eds.). Fuzzy set approach to multidimensional poverty measurement. (pp.49-72). Springer-Verlag, New York: Springer, Boston,MA.

CHOWDHURY, S., \& SQUIRE, L. (2006). Setting weights for aggregate indices: An application to the commitment to development index and human development index. Journal of Development Studies, 42(5), 761-771. doi: https://doi.org/10.1080/00220380600741904

CHUKWUMA, D. C. (2013). Poverty trap in Nigeria: a multidimensional perspective. (Unpublished thesis). Nnamdi Azikiwe University, Awka, Nigeria.

CUNGUARA, B. A. (2008). Pathways out of poverty in rural Mozambique. (Unpublished masters thesis). Michigan State University.

DAHL, E., FLOTTEN, T., \& LORENTZEN, T. (2008).

Poverty dynamics and social exclusion: An analysis of Norwegian panel data. Journal of Social Policy, 37(2), 
231-249.

https://doi.org/10.1017/S0047279407001729

doi: FINN, A., \& LEIBBRANDT, M. (2013). The dynamics of poverty in the first three waves of NIDS. (Southern Africa labour and development research unit working paper No.119). Retrieved from: https://ideas.repec.org/p/ldr/wpaper/119.html

GARBA, A. (2006). Alleviating poverty in northern Nigeria. A paper presented at the annual convention of Zumunta Association, Minneapolis, MN, USA, July 2829.

GASS, G., \& ADETUNMBI, D. (2000). Summary report of DFID's civil society consultation process in Nigeria, 13 December 1999 - 2 February 2000. Retrieved from dfid database

GOTTSCHALK, P., MCLANAHAN, S., \& SANDEFUR, G. D. (1994). The dynamics and intergenerational transmission of poverty and welfare participation. In Danziger, S. H., Sandefur, G. D., \& D.H Weinberg (Eds.), Confronting Poverty: Prescriptions for Change (pp. 85108). New York, NY: Russell Sage Foundation

HOKAYEM, C., \& HEGGENESS, M. L. (2013). Factors influencing transitions into and out of near poverty: 20042012. (SEHSD Working Paper, 2014-05). Retrieved from: https://www.census.gov/library/workingpapers/2013/demo/SEHSD-WP2013-02.html

IFAD. International Fund for Agricultural Development. (2012). Enabling poor people to overcome poverty. Retrieved from www.ifad.org

JUSTINO, P., LITCHFIELD, J., \& PHAM, H. T. (2008). Poverty dynamics during trade reform: evidence from rural Vietnam. Review of Income and Wealth, 54(2), 166192. doi: https://doi.org/10.1111/j.14754991.2008.00269.x

KAY, C. (2006). Rural poverty and development strategies in Latin America. Journal of Agrarian Change, 6(4), 455-508. doi: https://doi.org/10.1111/j.14710366.2006.00132.x

KUMAR, N., \& AGNES, Q. (2014). Gender, shocks and resilience, building resilience for food and nutrition security. 2020 Conference brief 11. May 17-19 2014, Addis Ababa, Ethiopia. Washington, D.C. Retrieved from http://www.ifpri.org/publication/gender-shocks-and-

resilience

LIBRARY OF CONGRESS. (2008). Country profile: Nigeria. Retrieved from http://lcweb2.loc.gov/frd/cs/profiles/Nigeria.

MAGGIO, G. (2004). Multidimensional analysis of poverty dynamics in Great Britain. (ISER Working Papers 2004-10). Retrieved from: https://www.iser.essex.ac.uk>...PDF multidimensional MPPN. Multidimensional Poverty Peer Network. (2017). National Multidimensional Index for Nigeria. Retrieved from. https://mppn.org/nigeria-national-mpi.

NBS. National Bureau Of Statistics. (2005). Poverty profile for Nigeria. Retrieved from nbs Nigeria database OBADAN, M. I. (2001). Poverty reduction in Nigeria: The way forward. CBN Economic and Financial Review, 39 (4), $159-188$.

OMOTOLA, J. S. (2008). Combating poverty for sustainable human development in Nigeria: The continuing struggle. Journal of Poverty, 12(4), 496 - 517. doi: https://doi.org/10.1080/10875540802352621

OPHDI. Oxford Poverty and Human Development Initiative. (2014). Country Briefing January: Nigeria Retrieved from ophdi database.

OVWASA, L.O. (2000). Constraints on poverty alleviation in Nigeria. Political Science Review, 1 (1), 56 $-80$.

OYEMOMI, E.O. (2003). An assessment of poverty reduction strategies in Nigeria 1983 - 2003 (Unpublished $\mathrm{Ph}$. D dissertation). St Clements University, The Turks and Caicos.

SEN, A. K. (1999). Development as Freedom (1). United States of America: Oxford University Press.

THORBECKE, E. (2005). Multi-dimensional poverty: conceptual and measurement issues. A paper prepared for the many dimensions of poverty international conference, UNDP International Poverty Centre, Brasilia. Retrieved from https://thorbecke.economics.cornell.edu > ...PDF

UNDP. United Nations Development Programme. (2002). World Energy Assessment. Retrieved from UNDP database.

UNDP. United Nations Development Programme. (2010). Human Development Report 2010: The real wealth of nations: Pathways to human development. Retrieved from UNDP database.

UNDP. United Nations Development Programme. (2014). Human development report 2014: Sustaining human progress: Reducing vulnerability and building resilience. Retrieved from UNDP database.

UNITED NATIONS. (2003). Indicators for Monitoring the Millennium Development Goals, New York: United Nations.

VALLETTA, R. G. (2006). The ins and outs of poverty in advanced economies: Government policy and poverty dynamics in Canada, Germany, Great Britain, and United States. Review of Income and Wealth, 52(2), 261-284. doi: https://doi.org/10.1111/j.1475-4991.2006.00187.x 